Татарникова А. И. Противоэпидемические мероприятия органов городского самоуправления в Западной Сибири в конце XIX - начале XX веков / А. И. Татарникова // Научный диалог. - 2021. - № 3. - C. 452-468. - DOI: 10.24224/2227-1295-2021-3-452-468.

Tatarnikova, A. I. (2021). Anti-epidemic Measures of Municipal Authorities in Western Siberia in Late XIX — Early XX Centuries. Nauchnyi dialog, 3: 452-468. DOI: 10.24224/2227-1295-20213-452-468. (In Russ.).

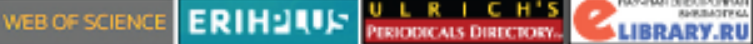

Журнал включен в Перечень ВАк

DOI: $10.24224 / 2227-1295-2021-3-452-468$

Противоэпидемические мероприятия органов городского самоуправления

в Западной Сибири в конце XIX - начале XX веков

Татарникова Анна Ивановна orcid.org/0000-0002-0854-4956 кандидат исторических наук, старший научный сотрудник tatob777@yandex.ru

федеральное государственное бюджетное учреждение науки Тобольская комплексная научная станция Уральского отделения Российской академии наук

(Тобольск, Россия)

\section{Anti-epidemic Measures of Municipal Authorities in Western Siberia in Late XIX - Early XX Centuries}

\author{
Anna I. Tatarnikova \\ orcid.org/0000-0002-0854-4956 \\ $\mathrm{PhD}$ in History, Senior Researcher \\ tatob777@yandex.ru
}

Tobolsk complex scientific station of the Ural Branch

of the Russian Academy of Sciences

(Tobolsk, Russia)

(С Татарникова А. И., 2021 


\section{ОРИГИНАЛЬНЫЕ СТАТЬИ}

\section{Аннотация:}

Рассматриваются события в конце XIX начале XX веков в Западной Сибири, где население пережило несколько эпидемий холеры, сыпного и брюшного тифа, кори и других инфекционных заболеваний. Отмечается, что печальным итогом вспышки многих инфекций являлась высокая эпидемическая смертность населения. Изучается деятельность органов городского самоуправления по профилактике распространения повальных болезней и борьбе с ними, по предотвращению высокой летальности среди заболевших. Анализируются предпринимаемые местными властями противоэпидемические меры: увеличение расходов на городское благоустройство; издание обязательных санитарных постановлений; создание врачебно-санитарных исполнительных комиссий; разделение территории города на участки и закрепление за ними санитарных попечителей; устройство бактериологических лабораторий, заразных бараков и дезинфекционных камер; санитарное просвещение населения. Делается вывод о позитивных изменениях в профилактике и лечении ряда инфекционных заболеваний, организации санитарного надзора за состоянием источников водоснабжения, мест продажи продуктов питания, содержанием помойных и выгребных ям, сваливанием нечистот на строго отведенные для этого территории. При этом обращается внимание на сохранение высокой эпидемической смертности (особенно младенческой) вследствие низкого уровня жизни большинства горожан, недостаточного питания, слабого развития гигиенических навыков, неосведомленности о причинах и способах лечения болезней.

\section{Ключевые слова:}

история России; история Сибири; противоэпидемиологические мероприятия; городское самоуправление; городское и земское здравоохранение.

\section{ORIGINAL ARTICLES}

\section{Abstract:}

The events in the late XIX - early $\mathrm{XX}$ centuries in Western Siberia, where the population survived several epidemics of cholera, typhus and typhoid fever, measles and other infectious diseases, are considered. It is noted that the sad result of the outbreak of many infections was the high epidemic mortality of the population. The activity of municipal authorities on the prevention and control of the spread of widespread diseases, the prevention of high mortality among the sick is being studied. The anti-epidemic measures taken by local authorities are analyzed: an increase in expenditures for urban improvement; the publication of mandatory sanitary regulations; creation of medical and sanitary executive commissions; division of the city territory into sections and assignment of sanitary guardians to them; arrangement of bacteriological laboratories, infectious barracks and disinfection chambers; health education of the population. The conclusion is made about positive changes in the prevention and treatment of a number of infectious diseases, the organization of sanitary supervision over the state of water supply sources, places of sale of food, the maintenance of garbage and cesspools, the dumping of sewage on strictly designated areas. At the same time, attention is drawn to the persistence of high epidemic mortality (especially infant mortality) due to the low standard of living of most of the townspeople, malnutrition, poor development of hygiene skills, lack of awareness of the causes and methods of treating diseases.

Key words:

history of Russia; history of Siberia; antiepidemiological measures; city government; urban and rural health care. 


\section{Противоэпидемические мероприятия органов городского самоуправления в Западной Сибири в конце XIX - начале ХX веков}

() Татарникова А. И., 2021

\section{1. Введение}

Одной из самых серьезных проблем, стоящих перед мировым сообществом на современном этапе его развития, является распространение новой коронавирусной инфекции, приобретшей характер пандемии. Вспышки инфекционных заболеваний, принимавших масштабный или локальный характер, сопровождали человечество на протяжении всей истории его существования. Население России, как и других стран, неоднократно сталкивалось с эпидемиями оспы, чумы, холеры, кори, различных форм тифа и других острых заразных инфекций, уносивших тысячи человеческих жизней. Сформировавшиеся в условиях частых эпидемий индивидуальные стратегии выживания, а также административные практики, выработанные центральными и местными властями в ходе борьбы с той или иной «заразой», легли в основу противоэпидемических мероприятий, направленных на прекращение заболевания. Изучение накопленного многовекового опыта противостояния различным инфекциям позволит определить эффективные способы борьбы с их распространением и негативными последствиями.

Исследование различных аспектов деятельности органов городского самоуправления по профилактике и борьбе с распространением инфекционных заболеваний населения в Российской империи и ее отдельных регионах не приобрело широкого масштаба.

Работы ученых дореволюционного периода носят преимущественно описательный характер: изучаются причины, симптомы и последствия инфекционных заболеваний [Гезер, 1867; Гамалея, 1905; Эрисман, 1893]. В трудах представителей томской медицины: А. И. Судакова, А. А. Грацианова, К. М. Гречищева - инфекционные заболевания рассматриваются как одна из распространенных причин смертности населения, особенно младенческой [Грацианов, 1903; Гречищев, 1912, с. 64-71; Судаков, 1894].

В историографии советского периода, в работах Г. А. Бейлихиса, Г. М. Вайдраха, А. Н. Сысина, З. П. Соловьева, отмечаются необеспеченность регионов медицинскими кадрами, неспособность местных администраций эффективно решать проблемы сохранения здоровья населения, определяется личный вклад врачей в дело борьбы с «заразой» [Бейлихис, 
1957; Вайдрах, 1959; Сысин, 1922, с. 263-266; Соловьев, 1932]. В исследовании Н. П. Федотова и Г. И. Мендриной на материалах сибирских архивов описано появление и течение инфекционных заболеваний, охарактеризована роль органов местного самоуправления в развитии медицинской помощи населению [Федотов и др., 1975].

К фундаментальным научным трудам постсоветского периода относятся работы И. Г. Васильева, Т. С. Сорокиной, В. О. Самойлова [Васильев, 2001; Самойлов, 1997; Сорокина, 1994], в которых анализируется опыт борьбы с различными инфекциями, приводится богатый фактологический материал по влиянию эпидемий на привычный уклад жизни людей.

В публикациях сибирских историков: В. А. Зверева, О. В. Чудакова, Э. Е. Шумиловой, А. Б. Храмцова - исследуются жизнесохранительное поведение отдельных социальных групп в период эпидемий, действия местных органов власти по санитарному просвещению населения, осуществлению санитарного надзора, профилактике вспышек острозаразных инфекций [Зверев, 1998; Храмцов, 2019, с. 1292-1300; Чудаков, 2012, с. 17-20; Шумилова, 2016, с. 24-30].

В целом в историографии проделана большая работа по изучению истории борьбы с эпидемиями в России и на ее отдельных территориях. Однако остаются слабо изученными вопросы, касающиеся организации и проведения противоэпидемических мероприятий органами местного самоуправления, взаимодействия власти с общественными организациями и активной частью населения, оценки эффективности действий органов власти в этой сфере.

Объектом настоящего исследования выступают массовые эпидемии конца XIX — начала XX веков, предметом - действия органов местного самоуправления по профилактике и борьбе с «повальными болезнями» среди городского населения Западной Сибири.

Цель работы - рассмотреть комплекс противоэпидемических мероприятий, проводимых органами местной власти в городах Западносибирского региона на рубеже XIX-XX веков, оценить их эффективность в снижении негативных последствий острых инфекционных заболеваний.

Основой источниковой базы исследования стали циркуляры и инструкции министерства внутренних дел (МВД), определяющие действия органов общественного самоуправления по предупреждению инфекционных заболеваний и борьбе с ними; отчеты медицинского департамента МВД о заболеваемости и смертности населения от разных инфекций; ключевые положения «Врачебного устава» (1857 и 1892) о принятии мер, препятствующих распространению «повальных болезней». При написании работы также были задействованы постановления городских органов са- 
моуправления о мерах по улучшению санитарной обстановки, предупреждению заноса острозаразных инфекций и преодолению их последствий; врачебные отчеты по городам Западной Сибири за 1880-1916 годы; обзоры губерний, содержащих сведения об эпидемиях и предпринимаемых на местах шагах по их преодолению.

Индикатором, позволяющим проследить отношение городской общественности к действиям местных властей по борьбе с распространением эпидемий, является периодическая печать. В изданиях конца XIX - начала XX веков («Тобольские губернские ведомости», «Томские губернские ведомости», «Сибирский врач», «Сибирская врачебная газета» и др.) отразилась повседневная жизнь горожан в условиях свирепствовавших инфекционных заболеваний, а также взаимодействие органов местного самоуправления с населением по вопросам предупреждения новых вспышек «заразы» и стратегий поведения во время эпидемий.

Методологическую основу работы составили идеи теории модернизации, согласно которым на рубеже XIX-XX веков происходили социокультурные трансформации, связанные с переходом от традиционного к индустриальному обществу и сопровождавшиеся изменениями в общественном сознании, ценностно-смысловых установках и поведенческих практиках.

\section{2. Санитарно-эпидемиологическая обстановка в городах Западной Сибири в конце XIX - начале XX веков}

Одной из распространенных причин высокой смертности населения в Российской империи на протяжении многих веков были инфекционные заболевания. Свирепствовавшие эпидемии оспы, холеры, дизентерии, брюшного и сыпного тифа, гриппа, кори, чумы ежегодно уносили жизни десятков тысяч человек. Большие людские потери во время вспышек острозаразных инфекций несли не только густонаселенные губернии европейской части страны, но и ее окраинные территории. Слабая эффективность системы управления, низкий уровень транспортной доступности, отсутствие развитой медицины, а также нищета, невежество, антисанитарные условия жизни населения, национальные и культурные традиции ведения быта аборигенными народами накладывали свой отпечаток на эпидемиологическую обстановку в периферийных регионах.

Не обошли стороной «повальные болезни» и Западную Сибирь, остававшуюся до 1890-х годов одной из слабоосвоенных окраин Российской империи. В разные годы здесь наблюдались крупные вспышки холеры, брюшного и сыпного тифа, скарлатины, оспы, дизентерии и других инфекций. 
Отсутствие возможности получить доступную медицинскую помощь, консервативные установки населения в отношении способов лечения «поветрий», несоблюдение элементарных правил гигиены, плохое питание и другие факторы провоцировали частые вспышки острозаразных инфекций, заканчивающихся для многих людей летальным исходом. Так, в 1887-1890 годах из 100 тыс. жителей Тобольской губернии от дифтерита умирали 16,5 человек; дизентерии - 14,5; оспы - 12,6; скарлатины - 7,8; брюшного тифа — 7,5. В Томской губернии в аналогичное время показатели эпидемической смертности были еще выше. Наибольшее число жизней уносила оспа. На 100 тыс. населения показатель смертности от названной инфекции составлял 28,4 чел., дизентерии - 17,8; брюшного тифа - 15,4; скарлатины - 11,7; кори — 11,4 [Отчет ..., 1889-1892].

Негативное влияние на возникновение и продолжительность эпидемических заболеваний оказывал дефицит медицинских кадров. К 1914 году в Сибири один врач приходился на 10200 жителей, в то время как в целом по стране - на 5140. В сибирских городах один врач обслуживал 1760 человек, в российских городах в среднем - около 1200. В сельской местности нагрузка на врачей была гораздо выше. В Сибири на одного врача приходилось 23000 селян, в то время как в империи в целом - 7500 [Глушков, 2011, с. 347].

Ключевое значение в появлении острых заразных инфекций имело санитарное состояние населенных пунктов, большинство из которых отличалось низким уровнем благоустройства, загрязненностью нечистотами, отсутствием канализации, некачественным водоснабжением и т. п.

Антисанитария в сибирских городах и селениях неоднократно отмечалась в отчетах различных ведомств, записках путешественников, местной периодической печати. К примеру, в отчете врачебной управы Томской губернии за 1882 год указывалось, что «непременной принадлежностью» местных городов являлись «непроходимая грязь, кучи навоза, валяющиеся местами дохлые кошки и собаки, разливающаяся по улицам вонючая жидкость, выкачанная из погребов и помойных ям» [Обзор ..., 1883, с. 51]. Города Тобольской губернии также не отличались чистотой. Свою лепту в неприглядную картину санитарного состояния городов вносило их природно-географическое положение. Так, губернский Тобольск, расположенный преимущественно на болотистой низине, испытывал ежегодные весенние и осенние поднятия вод р. Иртыш, что становилось причиной наводнений и увеличивало болотные испарения. По замечанию губернатора А. С. Сологуба, это порождало тиф, лихорадки, дизентерию и другие болезни, принимавшие эпидемический характер [Тобольские ..., 1893, 10 марта].

В 1900-е годы наметился рост западносибирских городов. Он происходил в основном за счет притока неимущего населения, оседавшего на 
окраинах, вблизи действовавших фабрик и заводов. Жилища этой части горожан отличались неблагоустроенностью, были лишены элементарных санитарных удобств. Неудивительно, что именно городские окраины становились рассадниками различных инфекций.

В обстановке царившей в городах антисанитарии, загрязнения источников водоснабжения навозом и различными нечистотами, длительного отсутствия водопровода и канализации, плохих жилищно-бытовых условий, гигиенической безграмотности основной массы горожан вспышки острых инфекционных заболеваний часто приобретали эпидемиологический характер.

Пришедшийся на 1890-1910-е годы массовый наплыв переселенцев, усиление внутрирегиональных миграционных процессов усугубляли и без того неблагополучную санитарно-эпидемиологическую ситуацию. Тяжелые условия переселения, организационные просчеты властей, приводившие к скоплению значительного количества выходцев из европейской части страны в крупных транзитных пунктах (Тюмень, Омск, Новониколаевск), труднодоступность получения медицинской помощи в случае болезни, плохое питание способствовали появлению многочисленных инфекций.

Разносчиками инфекций были также арестанты, этапированные в регион к местам отбывания наказания. К примеру, в Омске в 1885 году после прибытия парохода «Звезда» с партией арестантов стала распространяться холера, поскольку часть осужденных оказалась больна этой «поветрей». В Томске первые случаи заболевания холерой в 1892 году также были зафиксированы среди арестантов, находившихся на приехавшей из Тюмени барже с пароходом «Галкин-Врасский». В последующие две-три недели острозаразная болезнь распространилась среди томичей и жителей губернии. В 1907 году холера была занесена в регион переселенцами, прибывшими по железной дороге.

В годы Первой мировой войны распространению инфекционных заболеваний способствовали беженцы и военнопленные, размещавшиеся преимущественно в городах. Так, в 1914 году в Новониколаевске городским властям пришлось принимать срочные меры по локализации эпидемии тифа, вспыхнувшей вскоре после прибытия пленных. Из 19903 военнопленных, находившихся в городе с сентября 1914 по июль 1915 года, названной инфекцией заболело 5328 человек, 2036 из них скончалось [Еремин, 2007, с. 260].

Распространение острозаразных болезней влекло за собой не только увеличение смертности, но и ухудшение благосостояния населения, замедление темпов развития экономики. В этой связи вопросы профилактики и борьбы с повальными болезнями приобретали особую актуальность и требовали от городских органов власти единых согласованных и эффективных действий. 


\section{3. Действия органов городского самоуправления по предупреждению и борьбе с эпидемическими заболеваниями}

Расширение возможностей городских самоуправлений по решению вопросов местного хозяйства и благоустройства вверенных им территорий связано с введением Городовых положений 1870 и 1892 годов.

Перечисленные законы возлагали на органы городского общественного управления попечение и надзор за внешним благоустройством: состоянием улиц, площадей, мостовых, тротуаров, водопроводов, сточных труб, прудов, канав, мостов и пр. Также к предметам ведомства органов городской власти были отнесены вопросы, касающиеся благосостояния населения: устройство рынков, базаров; обеспечение народного продовольствия; содействие развитию образования; забота об охранении народного здравия, в том числе принятие мер против распространения повальных болезней [Высочайше ..., 1892; Новое ..., 1871].

Спустя два года после принятия Городового положения 1870 года в большинстве городов Западной Сибири органами самоуправления были разработаны и приняты «обязательные постановления для местных жителей по улучшению санитарной части». В последующие годы эти постановления дополнялись отдельными статьями, подвергались незначительной корректировке с учетом происходивших изменений в жизни городских поселений. В целом в разных городах региона обязательные санитарные постановления издавались в 1872, 1879, 1890, 1901, 1912, 1914, 1916 годах [Обязательные ..., 1890; РГИА, ф. 1287, оп. 40, д. 1287, 1223, л. 21-62; Врачебно-санитарная ..., 1916, январь-февраль].

Несмотря на то, что указанные нормативно-правовые акты не содержали перечня мер, направленных непосредственно на борьбу с эпидемиями и их последствиями, они включали требования санитарного характера, призванные обеспечить нормальные условия жизнедеятельности горожан, минимизировать негативное влияние антисанитарной обстановки на здоровье населения. Постановления предписывали жителям содержать в чистоте придомовую территорию, не допускать скопления навоза и других нечистот, своевременно очищать помойные и выгребные ямы, вывозить их только на отведенные для свалки места. Горожанам запрещалось загрязнять источники водоснабжения, производить забой скота в жилых дворах, хранить сырые шкуры животных у себя дома. Обязательные постановления распространялись не только на население, но и на промышленные, торговые заведения городов, скотобойни, общественные бани, цирюльни и другие учреждения инфраструктуры.

В своих обязательных постановлениях думы имели право устанавливать сроки для очистки дворов, устройства и наведения чистоты на городских улицах, в промышленных и торговых заведениях. 
За нарушение санитарных правил предусматривалось взыскание в виде денежного штрафа, размер которого зависел от тяжести совершенного правонарушения. В 1864-1903 годах штраф для физических лиц составлял от 1 до 15 руб. [РГИА, ф. 1287, оп. 40, д. 1223, л. 22 об.].

Следить за соблюдением принятых обязательных постановлений должны были представители полиции. Однако на практике санитарные требования местных властей повсеместно игнорировались, а полиция бездействовала. Пренебрежительное отношение к предписаниям городских управ было обусловлено бытовавшими традиционными представлениями о способах ведения хозяйства, несформированностью необходимых культурно-гигиенических навыков поведения у подавляющего большинства горожан.

Существенное влияние на уровень развития муниципального хозяйства оказывала низкая обеспеченность городов финансами. Несмотря на увеличение в 1900-е годы расходов на медико-санитарное дело, выделяемых средств было явно недостаточно для решения всех вопросов, связанных с городским благоустройством и здравоохранением.

По данным Л. А. Ереминой, к 1913 году расходы на медицинскую, ветеринарную и санитарную части в крупных и средних городах Западной Сибири составляли от 10 до $15 \%$ бюджетных средств, в малых - 4-6 \%. Они включали содержание местных лечебных заведений, обслуживающего персонала, ветеринарной службы, а также затраты на санитарные мероприятия, в том числе противоэпидемические. В отдельные годы вспышки острых инфекционных заболеваний вынуждали органы городской власти увеличивать ассигнование врачебно-санитарной части в несколько раз, что нередко приводило к перерасходу и дефициту бюджетов [Еремина, 2005, с. 83].

Скудное финансирование статей, связанных с благоустройством городских территорий, снижало эффективность действий органов самоуправления по организации противоэпидемических мероприятий. Наиболее ярко это проявилось во время эпидемии холеры 1892 года, когда местным властям пришлось в максимально сжатые сроки произвести очистку улиц и площадей, источников водоснабжения, организовать уборку дворов горожанами, а также дезинфекцию помещений и вывоз нечистот.

Стремясь избежать большого числа жертв, органы самоуправления, проводя профилактические мероприятия, приказывали жителям под угрозой наказания произвести порядок во дворах, вывезти на городские отвалы нечистоты. С этой целью, как правило, власти крупных городов выделяли деньги на закупку дезинфицирующих средств, увеличение городского ассенизационного обоза. Примечательно, что специальный перевозочный транспорт, вывозивший фекальные нечистоты, существовал далеко не везде. В малых городах чаще всего ассенизацией занимались частные лица, 
средства из местных бюджетов на эти нужды не выделялись. В Новониколаевске, например, городская управа приняла решение об организации обоза лишь в 1910-1911 годах, после вспышки очередной «заразы».

Несмотря на проводимые в ожидании той или иной эпидемии мероприятия, местные власти и горожане зачастую оказывались неподготовленными к борьбе с «поветрей». Это наглядно показала эпидемия холеры 1892 года, унесшая в Западной Сибири жизни десятков тысяч людей.

Организация мероприятий по борьбе с холерой и другими инфекциями не отличалась планомерностью и носила преимущественно стихийный характер. Органы городского общественного управления экстренно открывали временные больницы, строили «заразные» бараки для размещения заболевших. В таких крупных городах, как Томск, Омск, Барнаул, Новониколаевск, Тюмень, власти выделяли средства из бюджета на проведение дезинфекции не только в общественных учреждениях, но и в домах малоимущих жителей. Последним услуга оказывалась бесплатно.

Преимущественно за счет городских средств осуществлялась дезинфекция колодцев, клозетов при общественных учреждениях, мест стирки белья и массового купания. В качестве дезинфицирующих средств использовались карболовая кислота, сулема, хлорная известь, формалин, креолин, лизол.

В ожидании эпидемии местные власти создавали запас медикаментов и дезинфицирующих средств, выделяли и готовили помещения для обсервации «подозрительных». В качестве дополнительной меры по недопущению развития «заразы» устанавливались посты санитарного досмотра поездов и речных судов, которые выявляли среди пассажиров лиц с признаками инфекции, отправляя их на лечение в больницы. Органы городского самоуправления активизировали свою работу по уничтожению грызунов (крыс, мышей и т. п.) с целью профилактики чумы и тифа.

Для очистки городских улиц и дворов, помойных и выгребных ям от нечистот, проверки состояния источников водоснабжения, ревизии промышленных и торговых заведений создавались особые санитарные комиссии, санитарно-эпидемические отряды, а города делились на санитарные участки, каждый из которых находился под наблюдением попечителей. Представители санитарных комиссий совершали обход жилых дворов, осматривая их на предмет соблюдения санитарных норм.

Масштабы загрязнения дворов впечатляли. К примеру, в Томске во время холерной эпидемии 1892 года, в период с 18 сентября по 12 октября, санитарной комиссией и городовым врачом было осмотрено 89 дворов в центре города. 60 из них оказались неочищенными от нечистот. У девяти домовладельцев скопилось столько грязи и отходов, что комиссия была вы- 
нуждена составить акты и наложить штрафы на нерадивых хозяев [ГАТО, ф. 3, оп. 2, д. 2304, л. 4-4 об.].

Проблема противодействия эпидемиям не теряла своей остроты и после 1892 года. В разные годы в западносибирских городах происходили вспышки оспы, брюшного, сыпного и возвратного тифа, кори, скарлатины, дизентерии и пр.

В начале XX века органы самоуправления активизировали свою деятельность по благоустройству городов, противодействию развитию заразных болезней среди жителей. Для предотвращения распространения инфекций в 1910-е годы управами Томска, Новониколаевска, Омска были закуплены дезинфекционные камеры. Средняя стоимость одной камеры составляла около 3500 рублей [Сибирская ..., 1910, 14 февраля]. Дефицит городского бюджета заставлял местные власти ходатайствовать перед правительственными учреждениями о выделении ссуд и займов. Так, в 1911 году Томская городская дума приняла решение возбудить ходатайство о выделении городу из казны ссуды в размере 50000 руб. на проведение противочумных мероприятий [Известия ..., 1911, январь, с. 33].

В Тобольске, Томске, Тюмени, Омске были устроены водопроводы. Хорошее качество водопроводной воды способствовало снижению случаев заболевания различными видами тифа, холерой. В 1911 году томский санитарный врач К. М. Гречищев отмечал: «Водопровод резко оборвал в Томске брюшной тиф, доведя его с 715 случаев в 1904 г. до 13-ти в 1909 г.» [Известия ..., 1911, 12-25 октября, с. 27].

В 1890-е годы в целях исследования качества питьевой воды в крупных городах открываются бактериологические лаборатории, на базе которых начинается производство противодифтерийной сыворотки. К началу Первой мировой войны жители Омска, Томска, Новониколаевска и ряда других городов могли сделать прививку от оспы, дифтерии, скарлатины, холеры. Тем не менее значительная часть горожан оставалась непривитой.

Анализ материалов местной периодической печати свидетельствует об активизации работы городских управ по санитарному просвещению населения. В «Губернских ведомостях» и других газетах все чаще публиковались статьи и заметки о способах профилактики и борьбы с различными «поветрями», средствах дезинфекции, важности соблюдения требований гигиены для предотвращения болезни.

Выделялись средства на массовое тиражирование листовок, содержащих рекомендации по предотвращению заразных болезней. Для разработки «наставлений на случай повальной болезни» городские самоуправления руководствовались соответствующими циркулярами Министерства внутренних дел, привлекали санитарных и городовых врачей, анализировали опыт 
борьбы с инфекцией в других губерниях страны. Санитарно-просветительская работа с горожанами в период эпидемий включала также организацию народных гигиенических чтений [Сибирская ..., 1910, 17 октября].

Положительные сдвиги в борьбе с эпидемиями в городах Западной Сибири нашли проявление в увеличении численности врачебного персонала, открытии на постоянной или временной основе специализированных учреждений для лечения «заразных» больных, налаживании сотрудничества с общественными организациями и инициативными представителями городского населения в деле профилактики «поветрей» и т. п.

Наметившаяся в 1900-е годы позитивная динамика в работе органов городской власти по противодействию распространению острозаразных инфекций была прервана начавшейся Первой мировой войной и последовавшими за ней политическими и социально-экономическими катаклизмами в стране. События 1914-1918 годов дестабилизировали жизнь общества, что отрицательно сказалось не только на благосостоянии, но и на здоровье населения, распространении инфекционных заболеваний и эпидемиологической смертности.

\section{4. Заключение}

Период конца XIX — начала XX веков отмечен усилением внимания органов городского самоуправления Западной Сибири к проблеме борьбы с распространением эпидемий, снижения высокого уровня эпидемической смертности населения.

Местные управы в условиях роста городов и числа их жителей, расширения селитебной площади и усложнения социальной инфраструктуры столкнулись с необходимостью оперативного решения вопросов антисанитарного состояния вверенных им для управления территорий, принятия мер по повышению доступности медицинской помощи горожанам, усиления административного надзора за соблюдением существующих санитарных требований.

Организация и проведение противоэпидемических мероприятий потребовали от городских управ совершенствования местной нормативноправовой базы в сфере благоустройства городов, обеспечения санитарного порядка, а также увеличения расходов на эти цели.

В сотрудничестве с полицией, врачебным персоналом, общественными организациями, инициативными горожанами органы самоуправления принимали меры по санитарной очистке городских территорий, осмотру прибывающих в города партий арестантов, ссыльных, переселенцев и других лиц, надзору за соблюдением обязательных санитарных постановлений.

Для оперативного противодействия распространению «заразительных» болезней среди населения создавались врачебно-санитарные испол- 
нительные комиссии, которые должны были обеспечивать согласованные действия органов власти, учреждений, предприятий и жителей города в решении вопросов дезинфекции, вывоза нечистот, наведения порядка во дворах, жилищах.

Достаточно эффективной мерой по борьбе с эпидемиями стало применение органами самоуправления практики разделения территории города на участки и закрепления за ними санитарных попечителей. Последние совершали осмотры дворов горожан, территорий промышленных и торговых заведений, источников водоснабжения, помойных и выгребных ям, составляя в случае серьезных нарушений санитарных постановлений протоколы на нерадивых хозяев, которым грозил штраф.

Частые вспышки эпидемий и высокий уровень заболеваемости населения заставили власти крупных городов Западной Сибири потратиться на устройство бактериологических лабораторий и «заразных» бараков, приобретение дезинфекционных камер, введение должности городского санитарного врача, увеличение городского ассенизационного обоза, проведение водопровода и пр.

В ожидании эпидемии органы самоуправления осуществляли закупку дезинфицирующих средств, старались обеспечить необходимый запас медикаментов в городских больницах и аптеках, произвести очистку улиц, тротуаров, сточных канав, оврагов, берегов рек и т. п.

В рассматриваемый период активизировалась деятельность городских управ по санитарному просвещению населения, разъяснению через листовки, брошюры, местные газеты, организацию общественных гигиенических чтений, лекториев мер по профилактике и борьбе с инфекционными болезнями.

Тем не менее, несмотря на перечисленные позитивные изменения в решении проблемы борьбы с эпидемиями, действия органов городского самоуправления зачастую носили краткосрочный характер. Принимаемые ими противоэпидемические меры были ответом на очередную вспышку инфекции, по окончании которой все мероприятия сворачивались. Это объяснялось дефицитом финансовых средств, проблемами в координации действий правительственных учреждений, губернской администрации и органов городской власти по борьбе с заразными болезнями.

Немаловажную роль в слабой эффективности предпринимаемых противоэпидемических усилий городских управ играли низкий уровень жизни подавляющей массы горожан, недостаточное питание, плохие жилищно-бытовые условия, несформированность необходимых культурно-гигиенических навыков поведения. Это способствовало сохранению высокой эпидемической смертности населения, особенно в младенческом возрасте. 
Наплыв беженцев и военнопленных в регион в годы Первой мировой войны серьезно усугубил санитарную обстановку в регионе.

Дефицит медицинских кадров, недостаток финансовых средств, дезорганизация деятельности санитарных комиссий, переустройство «заразных» бараков под помещения для размещения беженцев и военнопленных свели на нет все «благие порывы» по благоустройству городов в части наведения санитарного порядка. Это привело к развитию эпидемий холеры, сыпного и возвратного тифов, натуральной оспы, дизентерии и других инфекций, очагами которых становились в первую очередь крупные транзитные города Западной Сибири.

\section{ИСТОЧНИКИ И ПРИНЯТЫЕ СОКРАЩЕНИЯ}

1. Врачебно-санитарная хроника г. Томска. - 1916. - Январь-февраль.

2. Высочайше утвержденное 11-го июля 1892 года Городовое положение. - СанктПетербург : Тип. МВД, 1892. - 80 с.

3. ГАТО - Государственный архив Томской области. Ф. 3 (Томское губернское управление, 1822-1917). Оп. 2. Д. 2304. Л. $4-4$ об.

4. Известия Томского городского общественного управления - 1911. - Январь ; 12 - 25 октября.

5. Новое городовое положение, выс. утв. 16-го июня 1870 г., с приведением из Свода законов статей, на которые сделаны указания. - Москва : Тип. Бахметева, 1871. - 216 с.

6. Обзор Томской губернии за 1882 г. - Томск : Губ. тип., 1883. - 68 с.

7. Обязательные постановления Тобольской городской управы для местных жителей г. Тобольска. - Тобольск : Тип. Тобольского губ. прав., 1890. - 12 с.

8. Отчет Медицинского департамента МВД за ... [1889-1892 гг.]. — СанктПетербург : Тип. М-ва внутр. дел, 1891-1896.

9. РГИА - Российский государственный исторический архив. Ф. 1287 (Хозяйственный департамент МВД, 1797-1917). Оп. 40. Д. 1223. Л. 22 об. ; Д. 1223. Л. 21-62.

10. Сибирская врачебная газета. - 1910. - 14 февраля ; 17 октября.

11. Тобольские губернские ведомости. - 1893. - 10 марта.

12. Устав врачебный // Свод законов Российской империи. - Санкт-Петербург : Тип. Второго Отделения Е. И. В. Канцелярии, 1857. — Т. 13. - Тетр. 3. — 996 с.

\section{ЛИТЕРАТУРА}

1. Бейлихис Г. А. Из истории борьбы за санитарную охрану труда в царской России / Г. А. Бейлихис. - Москва : Медгиз, 1957. - 194 с.

2. Вайдрах Г. М. Подвиги русских врачей : Из истории борьбы с заразными болезнями / Г. М. Вайдрах. - Москва : Изд-во Акад. наук СССР, 1959. — 167 с.

3. Васильев И. Г. История эпидемий и борьба с ними в России в ХХ столетии / И. Г. Васильев. - Москва : Медицина, 2001. — 254 с. — ISBN 5-225-04452-2.

4. Гамалея Н. Ф. Холера и борьба с нею / Н. Ф. Гамалея. - Одесса : Типография Южно-русского общества печатного дела, 1905. - 124 с.

5. Гезер Г. История повальных болезней / Г. Гезер. - Санкт-Петербург : Медицинский департамент Министерства внутренних дел, 1867. - 430 с. 
6. Глушков C. E. Преобразование системы здравоохранения и снижение смертности населения в Западной Сибири конца XIX - начала XX вв. / С. Е. Глушков // Мир науки, культуры, образования. - 2011. - № 6 (31). - С. 336-349.

7. Грацианов А. А. Рождаемость и смертность в г. Томске с 1896-1902 г. / А. А. Грацианов // Сибирский вестник. - 1903. - № 189.

8. Гречищев К. М. Общественное здоровье / К. М. Гречищев // Город Томск. Томск : Издание Сибирского товарищества печатного дела в Томске, 1912. - 348 с.

9. Еремин И. А. Военнопленные Первой мировой войны в Западной Сибири / И. А. Еремин // Известия Томского политехнического университета. - 2007. Т. $3-10$. - № 1. - С. 259-263.

10. Еремина Л. А. Городское самоуправление Западной Сибири в конце XIX - начале XX веков / Л. А. Еремина. - Бийск : Изд-во Алт. гос. техн. ун-та, 2005. - 184 с.

11. Зверев B. A. Смертность сибирского населения на начальном этапе демографического перехода в России (конец XIX — начало XX в.) / В. А. Зверев // Региональные процессы в Сибири в контексте российской и мировой истории : сборник трудов. - Новосибирск : Ин-т истории СО РАН, 1998. - С. 53-57.

12. Самойлов В. О. История российской медицины / В. О. Самойлов. - Москва : Эпидавр, 1997. - 197 с. - ISBN 5-7939-0001-2.

13. Соловьев 3. П. Строительство советского здравоохранения / З. П. Соловьев. Москва : Медгиз, 1932. - 333 с.

14. Сорокина Т. С. История медицины / Т. С. Сорокина. - Москва : ПАИМС, 1994. - 381 c. - ISBN 5-87664-033-6.

15. Судаков А. И. Холерная эпидемия в Томске летом 1892 года / А. И. Судаков. Томск : Типо-лит. П. И. Макушина, 1894. - 135 с.

16. Сысин А. Н. Эпидемии в России в 1914-1922 гг. / А. Н. Сысин // Врачебная газета. - 1922. - № 1-11. - С. $263-266$.

17. Федотов Н. П. Очерки по истории медицины и здравоохранения Сибири / Н. П. Федотов, Г. И. Мендрина. — Томск : Изд-во Томск. ун-та, 1975. - 262 с.

18. Храмиов А. Б. Особенности становления и деятельности городского самоуправления в Новониколаевске (1895-1917) / А. Б. Храмцов // Былые годы. — 2019. T. 3. 一 № 53. - С. 1292-1300.

19. Чудаков O. В. Медико-санитарная деятельность органов городского самоуправления в Сибири в годы Первой мировой войны / О. В. Чудаков // Омский научный вестник. - 2012. - № 2 (106). - С. 17-20.

20. Шумилова Э. Е. Первая мировая война и уровень медицинского обслуживания населения в крупных городах Западной Сибири (1914-1917 гг.) / Э. Е. Шумилова // Вестник ТГУ. История. — 2016. — № 2 (40). — С. 24-30.

21. Эрисман $\Phi$. Ф. Холера. Эпидемиология и профилактика с общественно-санитарной точки зрения / Ф. Ф. Эрисман. - Москва : Типо-лит. Т-ва И. Н. Кушнерев и К, 1893. - $201 \mathrm{c}$.

\section{Material Resources}

GATO - State Archive of the Tomsk region. F. 3 (Tomsk provincial administration, 1822 1917). Op. 2. D. 2304. L. 4-4 vol. (In Russ.).

News of the Tomsk city public administration, January; 12-25 October. (1911). (In Russ.). The new City Regulations, issued on June 16, 1870, with the citation of the articles referred to in the Code of Laws. (1871). Moscow: Tip. Bakhmeteva. 216 p. (In Russ.). 
Mandatory resolutions of the Tobolsk City Council for local residents of Tobolsk. (1890). Tobolsk: Type. Tobolsk gubernia. Rights. 12 p. (In Russ.).

Medical and sanitary chronicle of Tomsk, January-February. (1916.). (In Russ.).

Medical regulations. (1857). Code of Laws of the Russian Empire in 13 vol., (3). Saint Petersburg: Type. The Second Department of the E. I. V. Chancellery. 996 p. (In Russ.).

Report of the Medical Department of the Ministry of Internal Affairs for ... [1889-1892]. (1891-1896). Saint Petersburg: Type. M-va internal affairs. (In Russ.).

RGIA - Russian State Historical Archive. F. 1287 (Economic Department of the Ministry of Internal Affairs, 1797-1917). Op. 40. D. 1223. L. 22 vol.; D. 1223. L. $21-62$. (In Russ.).

Review of the Tomsk province for 1882. (1883). Tomsk: Guberniya tip. 68 p. (In Russ.).

Siberian Medical newspaper, February 14; October 17. (1910). (In Russ.).

The City Regulations, which were approved by the Highest authority on 11 July. (1892). Saint Petersburg: Type. MVD. 80 p. (In Russ.).

Tobolsk provincial statement, 10 March. (1893). (In Russ.).

\section{REFERENCES}

Beilikhis, G. A. (1957). From the history of the struggle for sanitary labor protection in Tsarist Russia. Moscow: Medgiz. 194 p. (In Russ.).

Chudakov, O. V. (2012). Medico-sanitary activity of municipal self-government bodies in Siberia during the First World War. Omsk Scientific Bulletin, 2 (106): 17-20. (In Russ.).

Eremin, I. A. (2007). Prisoners of war of the First World War in Western Siberia. Proceedings of the Tomsk Polytechnic University, 3-10 (1): 259-263. (In Russ.).

Eremina, L. A. (2005). Urban self-government of Western Siberia at the end of the XIXbeginning of the $X X$ centuries. Biysk: Publishing house of Alt. state Technical University. un-ta. 184 p. (In Russ.).

Erisman, F. F. (1893). Cholera. Epidemiology and prevention from the public-sanitary point of view. Moscow: Tipo-lit. T-va I. N. Kushnerev and Co. 201 p. (In Russ.).

Fedotov, N. P., Mendrina, G. I. (1975). Essays on the history of medicine and health care in Siberia. Tomsk: Tomsk Publishing House. un-ta. 262 p. (In Russ.).

Gamaleya, N. F. (1905). Cholera and the fight against it. Odessa: Printing house of the South Russian Society of Printing 124 p. (In Russ.).

Gezer, G. (1867). History of general diseases. Saint Petersburg: Medical Department of the Ministry of Internal Affairs. 430 p. (In Russ.).

Glushkov, S. E. (2011). Transformation of the health care system and reduction of population mortality in Western Siberia of the late XIX - early XX centuries. The world of science, culture, and education, 6 (31): 336-349. (In Russ.).

Grazianov, A. A. (1903). Birth rate and mortality in Tomsk since 1896-1902. Siberian Bulletin, 189. (In Russ.).

Grechishchev, K. M. (1912). Public health. City of Tomsk. Tomsk: Publication of the Siberian Association of Printing Business in Tomsk. 348 p. (In Russ.).

Khramtsov, A. B. (2019). Features of the formation and activity of urban self-government in Novonikolaevsk (1895-1917). Bylyye gody, 3 (53): 1292-1300. (In Russ.).

Samoilov, V. O. (1997). History of Russian Medicine. Moscow: Epidaurus. 197 p. ISBN 5-7939-0001-2. (In Russ.). 
Shumilova, E. E. (2016). The First World War and the level of medical care of the population in large cities of Western Siberia (1914-1917). Bulletin of TSU. History, 2 (40): 24-30. (In Russ.).

Solovev, Z. P. (1932). Construction of Soviet healthcare. Moscow: Medgiz. 333 p. (In Russ.).

Sorokina, T. S. (1994). History of medicine. Moscow: PAIMS. 381 p. ISBN 5-87664-033-6. (In Russ.).

Sudakov, A. I. (1894). Cholera epidemic in Tomsk in the summer of 1892. Tomsk: Typo-lit. P. I. Makushina. 135 p. (In Russ.).

Sysin, A. N. (1922). Epidemics in Russia in 1914 -1922. Medical Newspaper, 1-11: 263266. (In Russ.).

Vaidrach, G. M. (1959). The exploits of Russian doctors: From the history of the fight against infectious diseases. Moscow: Publishing House of the Academy of Sciences of the USSR. 167 p. (In Russ.).

Vasiliev, I. G. (2001). The history of epidemics and the fight against them in Russia in the XX century. Moscow: Meditsina. 254 p. ISBN 5-225-04452-2. (In Russ.).

Zverev, V. A. (1998). Mortality of the Siberian population at the initial stage of the demographic transition in Russia (late XIX - early XX century). In: Regional processes in Siberia in the context of Russian and world history: a collection of works. Novosibirsk: Institute of History of the Siberian Branch of the Russian Academy of Sciences. 53-57. (In Russ.). 